УДК 004.822: 004.823

\title{
ПРЕДСТАВЛЕННЯ ЗНАНЬ В АДАПТИВНИХ СИСТЕМАХ ДИСТАНЦІЙНОГО НАВЧАННЯ
}

\author{
М. С. Дутчак \\ ДВНЗ "Прикарпатський національний університет імені Василя Стефаника"
}

\begin{abstract}
У статті описано побудовану модель представлення знань в адаптивних системах дистанційного навчання. Модель включає всі етапи функціонування бази знань системи, тобто збір, збереження, пошук і адаптивну видачу навчального матеріалу.
\end{abstract}

Ключові слова: представлення знань, база знань, адаптивна система дистанційного навчання.

\section{ПРЕДСТАВЛЕНИЕ ЗНАНИЙ В АДАПТИВНЫХ СИСТЕМАХ ДИСТАНЦИОННОГО ОБУЧЕНИЯ}

\author{
M. С. Дутчак \\ ГВУЗ “Прикарпатский национальный университет имени Василия Стефаника”
}

\begin{abstract}
В статье описано построенную модель представления знаний в адаптивных системах дистанционного обучения. Модель включает все этапы функционирования базы знаний системы, т.е. сбор, хранение, поиск и адаптивную выдачу учебного материала.

Основу адаптивных систем дистанционного обучения (АСДО) составляет база знаний. База знаний АСДО - это особого рода база данных, разработанная для управления знаниями (метаданными), т.е. сбором, хранением, поиском и адаптивной выдачей учебного материала. Модель представления знаний АСДО включает все этапы функционирования базы знаний.

В основу построенной базы знаний АСДО, ее наполнения и определения необходимых параметров каждого из элементов заложено фреймовую модель представления знаний. Но в отличие от классической модели, в которой отражен конечный вариант представления знаний, предложенная модель включает все этапы функционирования базы знаний.

Преимущества предложенной модели построения БЗ: четкая структурированность знаний, возможность динамического управления знаниями; необязательность определения всех параметров, возможность отслеживания и ручной режим изменения параметров; адаптивная выдача учебного материала.
\end{abstract}

Ключевые слова: представление знаний, база знаний, адаптивная система дистанционного обучения.

\section{KNOWLEDGE REPRESENTATION IN ADAPTIVE SYSTEMS OF DISTANCE LEARNING}

\begin{abstract}
SHEI "Precarpathian National University by V. Stefanyk"
In basis of adaptive distance learning systems ( ASDO ) laid a knowledge base. Knowledge Base ASDO - a special kind of database designed for knowledge management (metadata): collection, storage, retrieval and adaptive delivery of learning material. Model of knowledge representation ASDO includes all stages of functioning of the knowledge base.

The basis of the knowledge base of ASDO consist of frame-model of knowledge representation. But in contrast to the classical model, which reflected the final version of knowledge representation, the proposed model includes all stages of functioning of the knowledge base.

Benefits of the proposed model construction BZ: structuring knowledge, dynamic knowledge management; optionality determine all the parameters, the ability to track and manual change mode; adaptive issuing educational material.
\end{abstract}

M. S. Dutchak

Key words: knowledge representation, knowledge base, adaptive system of distance learning.

(C) М. С. Дутчак 
Вступ. У наш час, за умов стрімкого розвитку науки і техніки, фахівцеві потрібно навчатися практично все життя. Ідея "освіти впродовж усього життя" приводить до необхідності пошуку нових методів передачі знань і технологій навчання. Використання адаптивних систем дистанційного навчання (АСДН) відкриває нові можливості для безперервного навчання, комп'ютеризації традиційного навчання, отримання другої освіти, робить навчання доступнішим.

Інтелектуальне дистанційне навчання - це, насамперед, адаптивне навчання, яке враховує освітні потреби і цілі студента, наявні знання та навички, індивідуальні особливості. Терміном «студент» ідентифікується будь-яка особа, яка підвищує свій кваліфікаційний рівень з використанням АСДН.

Основу АСДН складає база знань (БЗ). База знань АСДН - це особлива база даних, розроблена для управління знаннями (метаданими), тобто збором, зберіганням, пошуком і адаптивною видачею навчального матеріалу (НМ). Модель представлення знань АСДН включає всі етапи функціонування БЗ.

Більшість БЗ наявних середовищ комп'ютерного навчання грунтуються на розміщенні в них електронних варіантів конспектів традиційних занять i статичній видачі НМ. Хоча можна виділити системи, при формуванні БЗ яких частково враховано принцип адаптивності. Наприклад, у СДТ REDCLASS відбувається формування групових/ індивідуальних навчальних програм/планів, управління заявками на навчання, управління доступом до навчання на основі тестування початкових знань. У системі ГЕКАДЕМ студент має змогу вибирати для себе найзручніший шлях для вивчення і працювати в індивідуальному режимі в оптимальний для себе час.[1,2].

Вивченням проблем представлення знань займались багато закордонних та вітчизняних вчених, зокрема: Р. Елліс, Х. Сінгх, М. Нічані, Р. К. Улен, П. І. Федорук. Проте питання представлення знань в АСДН вивчено недостатньо. Саме тому побудова і дослідження моделі представлення знань даних систем $\epsilon$ важливою та актуальною задачею.

Мета дослідження: проаналізувати етапи побудови баз знань для адаптивних систем дистанційного навчання.

Результати та їх обговорення. В основу побудованої БЗ АСДН, ії наповнення та визначення необхідних параметрів кожного із елементів закладено фреймову модель представлення знань. Але на відміну від класичної моделі, у якій відображено кінцевий варіант представлення знань, запропонована мо- дель включає всі етапи функціонування БЗ. Розглянемо їх більш детально.

3бір знань. Аналіз існуючих АСДН показав, що однією із основних причин уповільнення розвитку $і$ набуття популярності даних систем $\epsilon$ проблема "витягування" знань у викладачів. Наповнення БЗ АСДН навчальним матеріалом вимагає значних затрат часу і зусиль викладачів чи інженерів зі знань в процесі підготовки матеріалу для ідентифікації його складових частин і структурування їх в БЗ. Тому було поставлено за мету спрощення процедури підготовки НМ для його подальшого імпорту в БЗ без шкоди ефективності функціонування даних систем.

Основні вимоги, які ставляться до підготовки НМ на рівні лектора курсу для його автоматизованого внесення в БЗ АСДН:

- розбиття НМ на пункти плану і максимальну можливу кількість рівнів підпунктів із обов'язковою нумерацією кожного із пунктів та підпунктів і рекомендованим наданням заголовків. Нумерація стандартного виду: 2., 2.1, 2.2, 2.2.1 тощо;

- синтаксична незв'язність будь-якого із пунктів чи підпунктів плану із передуючим йому пунктом плану.

У загальному випадку цих двох вимог вистачає для поділу НМ на навчальні блоки (НБ).

Етапи підготовки НМ до внесення в Б3 на рівні інженера зі знань:

1. Заміна символів, що мають у HTML спеціальний сенс: < (менше), > (більше), \& (Амперсенд) і “ (лапки) відповідною комбінацією символів.

2. Перетворення вмісту лекції в HTML-код.

3. Збереження у текстовому форматі (кодування UTF-8).

Зберігання знань. Для формування БЗ АСДН важливим моментом $€$ квантування навчального контенту, яке полягає в його розбитті на складові частини, описі властивостей цих частин і встановленні взаємозв'язків між ними. Для представлення знань у вигляді ієрархічної організації фреймів (IОФ) весь НМ розбивається на НБ різних рівнів ісрархіі. Кількість рівнів залежить від глибини структурованості НМ. На найнижчому рівні ієрархії знаходяться кванти навчальної інформації (KHI).

Після поділу НМ на КНІ, для них встановлюються наступні параметри: синтаксичні, змістові та якісні коефіцієнти зв'язку, рівень складності, ступінь важливості, етап навчання тощо. При традиційному навчанні всі ці зв'язки, як правило, закладені в «інтелекті» викладача чи частково викладені на папір. 
Для занесення ієрархічної структури у БЗ кожен фрейм представляється у вигляді набору параметрів: $\left[\mathrm{ID}, \mathrm{I}, \mathrm{P}, \mathrm{C}_{1}, \mathrm{C}_{2}, \ldots, \mathrm{C}_{\mathrm{n}}\right]$, де

ID - унікальне ім'я фрейму;

I - інформаційна одиниця (об’єкт фрейму);

$\mathrm{P}$ - батьківський НБ;

$\mathrm{C}_{1}, \mathrm{C}_{2}, \ldots, \mathrm{C}_{\mathrm{n}}-$ слоти (заповнюються параметрами НБ).

Така ієрархічна структура дозволяє чітко структурувати НБ, зв'язувати їх з різнотипними параметрами, при чому встановлюються зв' язки не тільки між КНІ, але й між фреймами вищих рівнів ієрархіі [3].

Поиук та адаптивна видача знань. У завданнях моделювання, як правило, потрібно розробити групу сценаріїв розвитку досліджуваної системи на основі організації раціонального вибору кожної 3 вхідних в неї підсистем і узгодження взаємних зв' язків між ними. Для розробки цих сценаріїв і досягнення поставленої мети необхідно вирішити системні завдання оцінювання множини станів, характеристик функціональних елементів активного циклу діяльності кожної 3 підсистем.

При дистанційному навчанні для реалізації адаптації необхідна побудова математичної моделі навчального заняття як оцінки характеристик заняття, інформаційно-структурної моделі студента, а також ієрархічної системи заняття, яка б складалася із множини альтернатив проектних рішень на кожному ієрархічному рівні для формування навчального заняття. Із набору альтернатив формується навчальне заняття. Можна формалізувати процедуру вибору кращих в певному розумінні альтернатив із заданої множини.

Загальна мета побудови ієрархічної системи складових заняття полягає в отриманні із заданим ступенем достовірності і обгрунтованості змісту заняття, який найточніше відповідає особливостям студента. Для досягнення цієї мети стратегія побудови повинна забезпечувати раціональний вибір: ієрархічної структури заняття; розподілу вимог і функцій між різними ієрархічними рівнями; елементів і структури кожного ієрархічного рівня; функцій і параметрів функціональних елементів на кожному ієрархічному рівні.

Дані завдання зберігають такі властивості і особливості, як неформалізованість і багаторівневий прямий і зворотний параметричні взаємозв'язки. Наприклад, задача скорочення часу заняття в цілому параметрично взаємопов'язана із завданням мінімізації часу виконання НБ різних рівнів ієрархії, 3 яких складається заняття. Але одночасно це завдання виявляється функціонально взаємозв'язаним з іншими завданнями - зменшення обсягу поданого матеріалу, оптимізація методики викладання тощо

Виходячи із переліку ключових понять, які є кінцевою метою вивчення дисципліни і незнання яких визначено із початкового тестування, формується множина НБ, які містять ці поняття. Ці НБ називають ключовими. Виходячи із якісних, змістових та синтаксичних зв'язків визначаються спрямовуючі (допоміжні) НБ, які $є$ необхідними для достатнього засвоєння ключових НБ. Вони дозволяють встановити оптимальну послідовність навчання, забезпечити необхідний взаємозв'язок НМ, оскільки групуються взаємозалежні КНІ, що враховує той факт, що чим довший час між вивченням залежних квантів, тим більша ймовірність забування початкової інформації. Встановлені ступені важливості та рівні складності дають можливість коригувати зміст та складність викладу НМ відповідно до моделі студента. Поступове введення змістових, менш якісно залежних НБ чи роз'яснень існуючих знижує складність заняття.

Адаптивне представлення НМ здійснюється на основі продукційної моделі, відповідно до якої знання представляються у вигляді правил типу: «Якщо <умова> ТО <висновок>» [4]. В умові здійснюеться зіставлення параметрів студента і параметрів слотів фреймів, як результат одержуємо параметри індивідуальної траєкторії навчання.

Відповідно до запропонованої моделі, етап навчання визначається рівнем знань студента, складність заняття повинна відповідати ступеню сприйняття нових знань, послідовність викладу залежить від виявлених прогалин у знаннях ключових понять теми чи дисципліни в цілому із врахуванням встановлених змістових, синтаксичних та якісних зв'язків між НБ, ступенів важливості НБ.

Адаптивне представлення знань здійснюється на основі аналізу статистичних даних проходження занять студентами та оцінки ймовірнісних параметрів моделі студента та НM.

Отже, запропоновано новий підхід для вирішення проблеми ефективної побудови структури та наповнення Б3, механізму доступу до ії елементів, визначення параметрів НБ та адаптивного представлення знань в системах комп'ютеризованого навчання.

Переваги запропонованої моделі побудови БЗ:

- чітка структурованість знань;

- можливість динамічного управління знаннями;

- необов'язковість визначення усіх параметрів;

- можливість відслідковування і ручного режиму зміни параметрів;

• адаптивна видача НM. 
До теперішнього часу не запропоновані показники релевантності моделей знань. Водночас системи, які не мають механізмів для визначення релевантності, можуть зіткнутися з проблемами «комбінаторного вибуху». Саме ця проблема стає на черзі розвитку адаптивних систем.

\section{Лiтература}

1. http://www.redcenter.ru.

2. http://www.hecadem.irk.ru

3. Федорук П. І. Побудова бази знань адаптивних систем дистанщійного навчання на основі фреймової та продукційної моделей представлення знань / П. І. Федорук,
Висновки. 1. Запропонований новий підхід для вирішення проблеми ефективної побудови структури та наповнення баз знань.

2. Невідкладним завданням подальшого розвитку адаптивних навчальних систем $є$ розробка критеріїв релевантності знань.

М. С. Дутчак// УСиМ: Управляющие системы и машины. -2012. -№5. - C. 3-10.

4. Субботін С. О. Подання й обробка знань у системах штучного інтелекту та підтримки прийняття рішень : навчальний посіб̈ник / С. О. Суббботін. - Запоріжжя : ЗНТУ, 2008. $341 \mathrm{c}$. 